\title{
Effect of climatic factors on incidence of jassid, Empoasca kerri (Pruthi) infesting groundnut
}

\author{
A.N. MER, G.M. PARMAR*, R.M. VIKANI ${ }^{1}$ AND D.S. KELAIYA ${ }^{2}$ \\ Main Oilseed Research Station (J.A.U.), JUNAGADH (GUJARAT) INDIA \\ ${ }^{1}$ Department of Agricultural Chemistry and Soil Science, Junagadh Agricultural University, JUNAGADH (GUJARAT) \\ INDIA \\ ${ }^{2}$ Department of Plant Pathology, College of Agriculture (J.A.U.) AMRELI (GUJARAT) INDIA
}

\section{ARITCLE INFO \\ Received : 09.02.2016 \\ Revised : 15.09 .2016 \\ Accepted : 29.09.2016}

\section{KEY WORDS :}

Groundnut, Jassid, Population dynamics, Weather parameters

*Corresponding author:

Email : dr_gmparmar@ rediffmail.com

\begin{abstract}
Seasonal incidence of groundnut jassid, Empoasca kerri was studied during summer 2014-15, at College of Agriculture, Junagadh Agricultural University, Junagadh. Groundnut crop was infested by jassid, Empoasca kerri. The study revealed that the incidence of jassid started in $2^{\text {nd }}$ week of March which gradually increased and touched its peak during $3^{\text {rd }}$ week of April and then decreased in $4^{\text {th }}$ week of May. Relative humidity showed significant negative correlation with jassid population. Minimum temperature, mean temperature, evaporation and bright sunshine hours showed positive correlation with jassid population whereas, maximum temperature, morning relative humidity, mean relative humidity and wind speed showed negative correlation with jassid population.

How to view point the article : Mer, A.N., Parmar, G.M., Vikani, R.M. and Kelaiya, D.S (2016). Effect of climatic factors on incidence of jassid, Empoasca kerri (Pruthi) infesting groundnut. Internat. J. Plant Protec., 9(2) : 608-610, DOI : 10.15740/HAS/IJPP/9.2/608-610.
\end{abstract}

